\title{
GENERAL FEATURES OF ROAD CRASHES IN CLUJ COUNTY, ROMANIA. SPATIALITY AND CAUSALITY
}

\author{
Vasile ZOTIC \\ Babeş-Bolyai University, Cluj-Napoca, Faculty of Geography, Centre for Research on Settlements and Spatial \\ Planning, ROMANIA, vasile.zotic@ubbcluj.ro

\section{Diana-Elena ALEXANDRU*} \\ Babeş-Bolyai University, Cluj-Napoca, Faculty of Geography, Centre for Research on Settlements and Spatial \\ Planning, ROMANIA, diana.alexandru@ubbcluj.ro \\ * Corresponding author

\section{István-Oliver EGRESI} \\ Babeş-Bolyai University, Cluj-Napoca, Faculty of Geography, Centre for Research on Settlements and Spatial \\ Planning, ROMANIA, istvan.egresi@ubbcluj.ro \\ DOI: http://doi.org/10.23740/TID120205
}

\section{ABSTRACT}

Road crashes have become a serious issue, and their negative impact, both socially and economically, has been subject to policies and programmes worldwide as well as a research topic for numerous studies in various fields. The present study aims to identify and demonstrate the persistence of certain features related to the occurrence and location of road crashes in Cluj County, Romania, which is a territory recording a constant high road crash incidence in the last decade. We used descriptive statistics to illustrate the key features of road crashes occurring in urban and rural areas, by road type, within the administrative territory of Cluj County, Romania. The analysis was focused on four main aspects: causes, effects in terms of persons injured and deaths, occurrence by road type, and location within and outside urban areas. The years 2019, 2009, and 2018 were considered as reference moments for the values recorded for all indicators in the analysis. Results showed a general trend of decrease in road crash incidence in 2019 compared to 2009, which was also confirmed by the absolute and relative increase in the period 2018-2019. The most significant decrease was found in the number of deaths, especially in the case of road crashes occurring on national roads and urban streets, where the incidence is still quite high. However, when ranked considering the number of crashes caused, we noted the persistence of certain categories of triggering factors for the high incidence of road crashes related to both drivers and pedestrians. Road safety is very much related to the behaviour of all participants in traffic and not so much to the road infrastructure and quality, although road capacity may be a triggering factor for drivers' behaviour. Further measures are needed to enhance road safety and meet the European target of halving the road crash number and fatalities until 2020 and in the next decade.

Keywords: road safety, road crashes, patterns, causes and effects, spatial distribution

Cite this articleas: Zotic, V., Alexandru, D.-E. \& Egresi, I.-O. (2020). General Features of Road Crashes in Cluj County, Romania. Spatiality and Causality. Territorial Identity and Development, 5(1), 99-123. DOI: http://doi.org/10.23740/T ID120205

\section{INTRODUCTION}

Sustainability at any territorial level is partly expressed by road safety, which is one of the main issues addressed by international organizations worldwide. Once with increased mobility, traffic congestion on certain sections of road infrastructure, erratic behaviour of participants in road traffic, improper configuration, and underdeveloped road infrastructure, the risk of road 
crashes has enhanced and, more importantly, the rate of fatalities on the road has increased, as well.

Road injury prevention was first addressed by World Health Organisation in collaboration with the World Bank in 2004, in a first global report concluding that road traffic injuries were ranked $11^{\text {th }}$ among death causes worldwide and $13^{\text {th }}$ at the European level (WHO, 2004). The two subsequent global road safety reports reiterate the high attention needed for road crash risk prevention and for policies and measures to be instated by states to decrease the number of road fatalities, since road traffic injuries were found to still be a major health issue triggering high impact socially and economically (WHO, 2009, 2018). Much more, the last WHO report emphasized the risk of not meeting two of the targets proposed by Agenda 2030 for Sustainable Development under Sustainable Development Goals 3 and 11, namely to improve road safety in urban areas and halve the number of global deaths and injuries from road traffic accidents by 2020 (United Nations, 2015).

At the same time, we note the same concerns at the European level, which are reflected through the policies established towards enhancing road safety. The European Commission has acknowledged this issue of increased road injuries based on increased mobility and other factors as a common feature of all member states, for more than three decades. Once with the third European Road Safety Action Programme, the European Union set a common goal for halving the number of road crash victims in the European Union by 2010. The same target of a $50 \%$ decrease in the number of road deaths by 2020 was set to be achieved by all member states as a committed collaborative effort to create a common road safety area (European Commission, 2010).

Despite the discrepancies between the EU member states, they have all been encouraged to adopt and integrate the general governance framework and objectives established in 2010 regarding road safety in their national and local strategies, adapted to their distinctive contexts. The concrete measures proposed should be in line with the seven objectives addressing primarily the following aspects: continuous and enhanced education and training of road users, traffic management and enforcement of rules and regulations for road safety, quality of road infrastructure and vehicles, improvement of emergency and postinjuries services, and protection of vulnerable road users, such as pedestrians and riders of two-whee I vehicles (European Commission, 2010). The progress in the implementation of these objectives was debated in 2017, at the ministerial conference on road safety in Valletta and further encouragement was given to all member states for continuing their efforts in meeting the prior target (Council of the European Union, 2017).

Road safety is also found integrated in the safe mobility objective, which is a top priority of the third package of strategic objectives and measures of the European Commission focusing on safe, connected, and clean mobility for all citizens of the European Union (European Commission, 2018). This set of strategic objectives and measures and their targets have also been considered in the newest European Road Safety Policy Framework 2021-2030 - Next steps towards "Vision Zero", supporting and encouraging long-term European, national and local actions towards achieving the goal of zero fatalities in road transport by 2050 (European Commission, 2019).

In this context, this study aimed to assess the degree of road safety at the local and county level against the targets set at the international and European level. Cluj County, Romania, was the selected area for study. Accordingly, the analysis was focused on achieving the following objectives: illustrate the dynamics in the number of road crashes occurred on all road types at 
the county level, in rural and urban areas, recorded in 2019, compared to 2009 and 2018; identify and rank the most impacting causes triggering road crashes, comparatively, for the three reference years; and, show the spatial distribution and the most prone areas for crash incidence at the local level.

\section{THEORETICAL BACKGROUND}

\section{Literature review}

Traffic safety, road crash incidence, the identification of measures and strategies to decrease the negative socioeconomic impact of road crashes have been, and still are, topics of high interest worldwide. Road safety assessment studies have been conducted by approaching local, regional, or national case studies. Regardless of the size of the area under study or the road safety-related aspects discussed, most of the researches aimed to illustrate particular and general aspects of road infrastructure, traffic volume, causes and effects of road crash occurrence on different road types, road users' behaviour, spatial and temporal patterns of crash occurrence. The variability of reference periods is high as well, ranging from one-year periods up to decades.

Exploratory spatial and temporal analyses were conducted to identify patterns and trends of road crashes (Joneset al., 2008; Ouni \& Belloumi, 2018; Mahata, Narzary \& Govil, 2019; Eckhardt \& Thomas, 2005; Erdogan, 2009, Saeed et al., 2019). Urbanization and increased traffic volumes were shown to increase the risk of road crashes although of medium and minor severity impact. For instance, Cabrera-Arnau, Prieto Curiel \& Bishop (2020) studied the incidence of road accidents in relation to urbanization during a ten-year period (2008-2018), making distinction between the values of incidence in urban versus rural areas in England, and, in relation with the number of inhabitants in those areas, learning that minor and serious road crashes are more frequent in urban areas, whereas fatal accidents are more likely in rural areas.

Road safety assessments (including risk factors, road users' behaviour and other contextual circumstances) are of utmost importance to develop programmes regarding traffic management and sustainable national policies to ensure a safer infrastructure and a safer traffic for road users (Sakhapov \& Nikolaeva, 2018, Cabrera-Arnau, Prieto Curiel \& Bishop, 2020; Sandhyavitri et al., 2017; Mahata, Narzary \& Govil, 2019; Gichaga, 2017; Erdogan, 2009). Heydari et al. (2019) approached road safety as a major and persistent concern in low-income countries, in which case it is the results of several challenging aspects that need improvements. Papadimitriou et al. (2019) performed an extensive review of the literature approaching road crash risk factors aiming to hierarchize them in relation to road safety, which resulted in three categories of infrastructure risk factors: risky, probably risky and unclear.

Road crash triggering factors were also investigated along with the behaviour of drivers and other participants in traffic, in terms of inattention and distraction (Sundfør, Sagberg \& Høye, 2019), risky driving behaviour (Camden et al., 2019) or responsibility of drivers and riders (Garcia et al., 2019). Sakhapov \& Nikolaeva (2018) addressed the issue of traffic safety as a three-step process (creation, growth and consolidation), arguing for the importance of identifying risk factors and traffic safety problems for the proposal of the indicators to be monitored and measures to be implemented to decrease incidence rate and achieve a highquality traffic management. 
The end result and the synthetic impact of road crashes are computed in their costs. Regardless of their severity from minor to extreme are reflected in the financial burden at the local and national level, and their value varies largely. A comparative investigation of the final costs estimated for the European countries, consisting of medical, production, human, administrative, and other related should be exemplified and considered here, although Romania was not included in this study because of the lack of data (Wijnen et al., 2019).

In the last decade, road safety has been debated at the national level, as well. Studies reflected this issue on from several perspectives, most of them investigating road crashes in terms of occurrence, causes, degree of severity, and victims involved for different reference periods. Cadar, Boitor \& Dumitrescu (2017) examined the number of road crashes occurred on the national roads in Romania in relation to the traffic volume recorded in 2015, and illustrated the increase in traffic volumes, as one of the most influencing factors for the increase in the incidence of road crashes. Authors also emphasized the low number of research studies on road safety in Romania and the need for more research on the investigation, prediction, and prevention of road crashes in Romania. They proposed the international Highway Safety Manual Predictive Method as one of the tools that could be used for predicting traffic safety.

Târnu \& Deac (2018a) explored the main causes of road crashes in Romania in the period 2007-2016, and more thoroughly addressed the number of car crashes specifically caused by failing to yield the right of way. In a second study, the same authors analysed the situation of fatal car crashes in Romania in relation to the European and national goals related to road safety ( $50 \%$ reduction of road traffic fatalities in the European Union from 2011 to 2020). The analysis was made at the national and county level for the period 2010-2017, illustrating the main triggering factors (Târnu \& Deac, 2018b). Both studies were concluded by proposing a series of measures to be implemented, both at the national, regional, and local level for the reduction of the number of car crashes.

Other causes for road crashes were also addressed, namely weather conditions (Drosu, Cofaru \& Popescu, 2020), technical features and quality of vehicles (Coșciug, Ciobanu \& Benedek, 2017) emphasizing their relevance in increasing or decreasing road crash incidence on all types of rural and urban roads in Romania, over the periods 2011-2014 and 2008-2015. Călinoiu, Mincă \& Furtunescu (2012) revealed the material and health impact of car crashes recorded in Romania in 2009 by considering the causes, circumstances and effects, arguing for more research on this issue of road safety to contribute to the elaboration of policies and measures to alleviate the socio-economic impact of road crashes at the national level. In another study, the traits of persons involved in car crashes and affected to a certain degree (from slight to severe and fatal injuries) were analysed for the period 2005-2010 (Mincă et al., 2013). In this case, the authors also argued for an enhanced coordination of national policies with the European ones to achieve better results in decreasing the number of car crashes and fatalities at the national level.

The issue of road safety has been approached at a lower spatial scale, as well. In this regard, we note the analysis of risk-prone areas for road crashes involving school-aged pedestrians in the capital city of Romania, Bucharest (Ivan, Benedek \& Ciobanu, 2019). Authors addressed the issue of pedestrian safety based on data recorded between 2011 and 2016. Results showed that the most significant triggering factors for the occurrence of road crashes in large and agglomerated urban areas are over speeding and age of the drivers, the most prone time interval being the afternoon. An extensive presentation of road crash incidence and dynamics over a ten-year period (2009-2018) is found in the Substantiation Study on Transport and Communications as part of the Cluj County Spatial Plan (2020), focusing on the yearly, 
monthly, and spatial distribution of road crashes by road type in Cluj County in 2009 and 2018, and their effects in terms of vehicles and people involved, injuries and deaths.

Sibiu County was selected for the study of the volume and dynamics of road crashes for the period between 2010 and 2018 (Târnu \& Deac, 2019). Authors concluded that the main triggering factor of car crashes is human behaviour. Carașca, Hogea \& Hădăreanu (2019) found a high level of mortality when assessing road crashes that occurred in Mureș County during a two-year period based on the characteristics of the victims involved. Data was strictly related to victims declared dead at the scene, be them drivers, pedestrians, passengers, or other participants in traffic. Based on the information provided by the medical records and autopsy reports, they classified victims in relation to age, gender and particular behaviour aspects, namely alcohol drinking, concluding that the major causes for the high mortality in car crashes are road conditions and behaviour of participants in traffic. Pantea et al. (2018) approached the road safety issue from a different perspective, that of the behaviour of car passengers, based on information provided by young persons aged from 18 to 20, in Timiș County. Results showed the main predictors of travelling with drunk drivers. Having that drunken driving is one of the main factors increasing the risk of car crashes, these results should be considered when elaborating measures for the prevention of road crash occurrence.

Parts of the administrative area of Cluj County were taken as case studies in several articles. Road safety in Cluj County, expressed by road crash incidence in the period 2010-2014, was analysed by Ciobanu \& Benedek (2015). Authors assessed the degree of severity of road crashes and revealed their spatial characteristics at the county level, considering the number of vehicles involved, their socio-spatial distribution, and the correlation with the urbanization level. Cluj-Napoca municipality has been subject to studies referring mostly to road crash incidence, dynamics and patterns, spatial and time distribution. Ivan \& Haidu (2012) investigated the territorial and time distribution of road crashes in Cluj-Napoca, based on daily data over the period 2010-2012, to observe the dynamics and patterns of incidence seasonally and through a 24-hour period. Spatially, the highest number of crashes was found recorded on the major streets. In another study, Ivan et al. (2015) found the most vulnerable areas for the occurrence of road crashes in Cluj-Napoca city by correlating the number of crashes and lowlight conditions. The social aspects of car crashes in urban areas were evaluated focusing on the particular traits of the persons responsible for producing crashes in Cluj-Napoca Municipality in the period 2010-2013, both drivers and pedestrians (Benedek, Ciobanu \& Man, 2016). Authors also identified hotspots prone to road crashes within the city street network.

\section{Road crashes - an indicator of road safety}

Regardless of their severity, road crashes express the level of security in traffic. They can occur because of single or multiple factors, during the day or night, on any category of road, in any season of the year, within or outside the locality. Most of the time, several factors contribute simultaneously to their occurrence. They are mainly related to mechanical features of vehicles, human behaviour, environmental factors, road condition, nature and intensity of traffic, the number of existing conflict points in traffic (junctions), the diversity of traffic participants, etc. Road crashes are either the direct consequence of one single cause or of a combination of more. Although they may or may not result in human casualties, they always imply a certain extent of material damage due to the collision between vehicles or between vehicles and other obstacles on or off the road. On the other hand, depending on the severity of the crash, 
victims may be assigned to three different classes: slightly injured, seriously injured, and / or fatalities.

Statistically speaking, road crashes seem to occur randomly, but, when analysed, we can note a certain causal, temporal and spatial distribution in the territory or within the road network. At the national level, certain characteristics of location, cause, and impact are found (The General Inspectorate of the Romanian Police - Traffic Department, 2019). We selected and categorized them into four classes (location-related, cause-related, time-related, an d impactrelated) which we used as reference when discussing our case study. However, in this analysis, we did not go into the specific details of time regarding seasonality, daytime and night-time, since our focus was to reveal the level to which road crashes recorded in Cluj County regarding incidence in relation to location and cause fit into the national identified patterns. The following aspects were established as general features of road traffic and road safety at the national level, against which we will illustrate the particular characteristics found in the case of Cluj County, Romania.

\section{Location-related}

- although the most numerous road crashes occur on urban streets, they generate the lowest mortality rate;

- a significant number of highly severe road crashes occur on national roads, resulting in numerous injured and deaths;

- the fewest road crashes occur on motorways, which are considered the safest roads, but when they do occur, they have the most devastating effects, causing the second highest number of deaths after those on national roads;

- road crashes that occur at level railway crossings have a very high mortality rate (95\%), which makes these sections the most dangerous in the national road network;

\section{Cause-related}

- special road features are not a decisive factor that would absolutely increase the risk level of road crashes, so that it was concluded that more than $50 \%$ of road crashes in Romania occur on road sections without special characteristics;

- junctions and curves are the road elements causing a high risk of crashes. Regarding the victims involved, although determining a greater number of serious road crashes than the curve, the junction is the place where the number of seriously injured and dead is comparatively lower. Compared to the junction, the curve proves a higher risk of producing casualties, in this case more than twice as many people losing their lives, and a higher number of victims being seriously injured;

- about $90 \%$ out of the total number of severe crashes occur under normal weather conditions. However, although less numerous, severe road crashes produced in special weather conditions proportionally result in drastic consequences, expressed by the number of deaths and se rious injuries;

\section{Time-related}

- the monthly dynamics of road crashes are low in the first six months of the year, with an increase of $25 \%$ in the second half of the year, the maximum being recorded in AugustSeptember, the most severe crashes occurring in December-January, whilst the least severe in August; 
- the weekly dynamics of road crashes show a gradual increase in their number towards the end of the week, reaching a peak on Saturdays. This is directly related to the general weekly program of the population, with increased mobility during nonworking days and to the attitude associated with leisure activities (lack of focus / attention, haste, decreased caution, alcohol drinking, etc.);

- in a 24-hour interval, between midnight and 5 AM, a relatively low number of road crashes is recorded, followed by a sharp increase in number (4-5 times) until 8 AM. After a lull between 8 and $9 \mathrm{AM}$, there is another period of nine hours (09.00 - 18.00) of continuous increase in the number of road crashes, when the maximum of the day is also reached. After 6 PM, the number of crashes begins to gradually decrease until midnight.

Impact-related

- the most severe road crashes are those involving vehicles and pedestrians; they represent about one-third of the total annual number of crashes and generate the highest number of victims;

- the highest degree of severity in road crashes is mainly determined by frontal collision, vehicle rollover, and catching fire;

- although fewer in number, road crashes occurring before 8 AM and after 8 PM cause a higher mortality rate, which argues that under less intense traffic conditions, driver behaviour is more reckless, more risk-prone, with most of the crashes resulting in deaths;

- the highest number of road crashes of maximum severity are recorded on Sundays;

- crash severity degree varies from month to month; so that, if in the first half of the year, most of the road crashes occur on working days, in the second half of the year, there is a higher risk of road crashes during the weekends;

All road crashes result in material damage relative to vehicles, road infrastructure, facilities located near the road, destroyed goods, etc., and corresponding material and social costs calculated to cover the injury or death of the victims involved.

The material and social costs resulting from the injury or death of the persons involved in the crash are the most impressive and with long-lasting effects on multiple levels. In Romania, they were regulated by Law 265 of 2008 (The Romanian Parliament, 2008) laying down provisions on traffic safety management on roads, republished, with subsequent amendments and completions, based on which the Romanian Road Authority (RO: ARR) annually publishes the value of the average social cost of a crash resulting in death and of the average cost of a severe road crash (Table 1 ).

Table 1: Values of the average social cost of road crashes

\begin{tabular}{|l|l|r|r|}
\hline No. & \multicolumn{1}{|c|}{ Type of road crash } & $\begin{array}{c}\text { Average social cost } \\
\text { of one road crash (RON) }\end{array}$ & $\begin{array}{c}\text { Average social cost } \\
\text { of one road crash (EURO) }\end{array}$ \\
\hline Year $\mathbf{2 0 1 6}$ & 760,158 & 169,270 \\
\hline 1 & Severe crash with injuries & $4,883,603$ & $1,087,468$ \\
\hline 2 & Severe crash with fatalities & 770,040 & 168,569 \\
\hline Year 2017 & Severe crash with injuries & $4,947,090$ & $1,082,964$ \\
\hline 3 & Severe crash with fatalities & \multicolumn{3}{|c|}{} \\
\hline 4 &
\end{tabular}

Source of data: Romanian Road Authority, 2020 
The social cost of road crashes is a particularly important indicator in estimating the consequences they have on the economy and living standards. It includes the medical expenses of the injured persons (hospital-staying, recovery, treatment) and the human expenses, which are expressing the value of feelings, loss of life or the decrease in quality of life (The General Inspectorate of the Romanian Police - Traffic Department, 2019).

The general findings resulting from long observations and specific analyses, show that spatially crash occurrence depends on the technical characteristics and conditions of the road network, degree of motorization, traffic intensity, climatic and morphological characteristics of the territory, quality of road signs, policies and measures to prevent road crashes, risk awareness of road users, alternative and proactive solutions to eliminate the triggering causes, etc. Along with these well-established causes, the latest concluding remarks at the European level show an increasing significance of several other crash contributing factors that should be carefully considered, namely driver distraction by mobile devices, driving under the influence of alcohol or drugs, failure to wear safety equipment, cyclists and pedestrians increased vulnerability (European Commission, 2018). Therefore, the new road safety policies at the national level must consider the advancements in mobility and technology, which bring new challenges to all traffic participants and road safety must become a top priority.

\section{METHODOLOGY}

To illustrate the current level of road safety within the road network in Cluj County, data related to crash occurrence were analysed. Much more, to construct a complex image of the spatial features of road crashes and conclude with some patterns that create a territorial identity of road safety in Cluj County, we also considered suitable to comparatively analyse the data recorded in 2009 with data for two other reference years, 2009 and 2018. This is in line with the European model of reporting and assessing road safety to observe the recent dynamics. Thus, by exploratory analysis and using descriptive statistics, the data were evaluated quantitatively and qualitatively for three reference moments.

Data were freely provided by the Cluj County Police Inspectorate, subordinated to the General Inspectorate of the Romanian Police, Traffic Department (GIRPTD). Data consisted in recordings of road crashes and related information on the time of occurrence, administrative location and GPS coordinates along with several distinctive features of the road they occurred on (category, technical specifics - configuration, inclination, signs/signalling, restrictions, quality of the road surface), weather conditions whether normal or particular in relation to the moment of crash occurrence, the main cause and manner of production and impact details (vehicles and persons involved, injured and fatalities).

Data were statistically analysed relative to four main characteristics (number, main crash triggering cause, occurrence by road type and impact on traffic participants - drivers, passengers, and pedestrians), thus revealing the context and general characteristics of road safety in Cluj County. Data were further processed in ArcGIS to represent the spatial distribution of road crashes at the locality level and to observe their distribution within the road network of the county.

In line with the aim of the study, we proposed to address three research questions related to road safety in a NUTS 3 territory as a case study: Has the global and European road safety target for 2020 been met? Have there been any changes in the causes triggering road crashes 
in 2019 compared to 2009? and Are there any changes in the spatial distribution of car crash occurrence?

First, we presented the general features of the road network in Cluj County, by road type and length, and its spatial configuration, focusing mainly on the national, European and county roads, as the main access and transit corridors at the county level. Second, we computed road crash incidence at the county level in 2019 , by road types, including streets in built-up urban and rural settlements, and by locality. The impact of road crashes was illustrated by the number of vehicles and victims involved and by the crash severity level based on the number of slightly and severely injured persons. To be able to analyse the dynamics and comparatively describe crashes and their effects by road type and location within or outside the urban are as, we included data for 2009 and 2018. Thus, we could observe the absolute and relative increase in the number of crashes to assess the level to which the goal of halving the number of car crashes and fatalities during a ten-year period was met. Third, we identified and prioritized 24 main causes triggering road crashes in Cluj County and categorized them into human-related (driver- and pedestrian-), technical-related, and others. We then ranked them according to the number of crashes caused. We reflected the changes in the ranking for the three reference years considered, 2019, 2009, and 2018.

The present study is the first in this series and aims to highlight the spatial context and general characteristics of production and impact of road crashes. The results of this analysis represent the premise for conducting further in-depth studies, emphasizing particular aspects of road crash impact, severity and management in the current context of national territorial mobility.

\section{RESULTS AND DISCUSSION}

\section{Context and study area}

Road crashes tend to become one of the most challenging socioeconomic issues, ending thousands of innocent lives every year, changing destinies, and leaving deep traces in the families of those involved. Despite the modern times we live, with increasing technology and numerous technical advances, this phenomenon has aggravated. The identification of causes triggering road crashes, road crash management, finding methods and means of combating road crashes along with careful observation of their spatial distribution to identify critical points (black spots) in which to intervene technically to reduce or eliminate them are all essential actions which have been pursued internationally and nationally. There are several aspects that can be observed when analysing the spatial distribution of road crashes, namely causal patterns, mode of production, resulting effects, location which, once established, may indicate the existence of dangerous road sections and critical points.

The present study aims to identify and demonstrate the existence of particular characte ristics of production and location of road crashes in Cluj County, Romania, as a case study.

Table 2: Road deaths per million inhabitants - preliminary data for 2019

\begin{tabular}{|c|c|c|c|c|c|c|}
\hline \multirow{2}{*}{ No. } & \multirow{2}{*}{ Country } & \multicolumn{3}{|c|}{ Year } & \multirow{2}{*}{$\begin{array}{c}\text { Change 2018-2019 } \\
\text { (\%) }\end{array}$} & \multirow{2}{*}{$\begin{array}{c}\text { Change } 2010-2019 \\
(\%)\end{array}$} \\
\hline & & 2010 & 2018 & 2019 & & \\
\hline 1 & Romania & 117 & 96 & 96 & 0 & -22 \\
\hline 2 & EU & 67 & 52 & 51 & -2 & -23 \\
\hline
\end{tabular}

Source of data: European Commission (2020) 
In this context, in the last decade, both Romania and Cluj County have consistently individualized as having a high accident rate. In the last decade, at the EU level, Romania was ranked first regarding road crash incidence resulting in deaths per 1 million inhabitants (European Commission, 2020), which is almost double the European average (see Table 2) and this is one reason for a complex study of this social phenomenon and propose practical measures to achieve a lowerincidence rate.

At the national level, Cluj County is ranked among the top five counties regarding the number of road crashes and first in the North-West Development Region during the entire reference period. These constantly high values of road crash incidence recorded in Cluj County, require a complex analysis of the phenomenon to identify the causality, patterns, effects and espe cially the critical points within the road network (Figure 1).
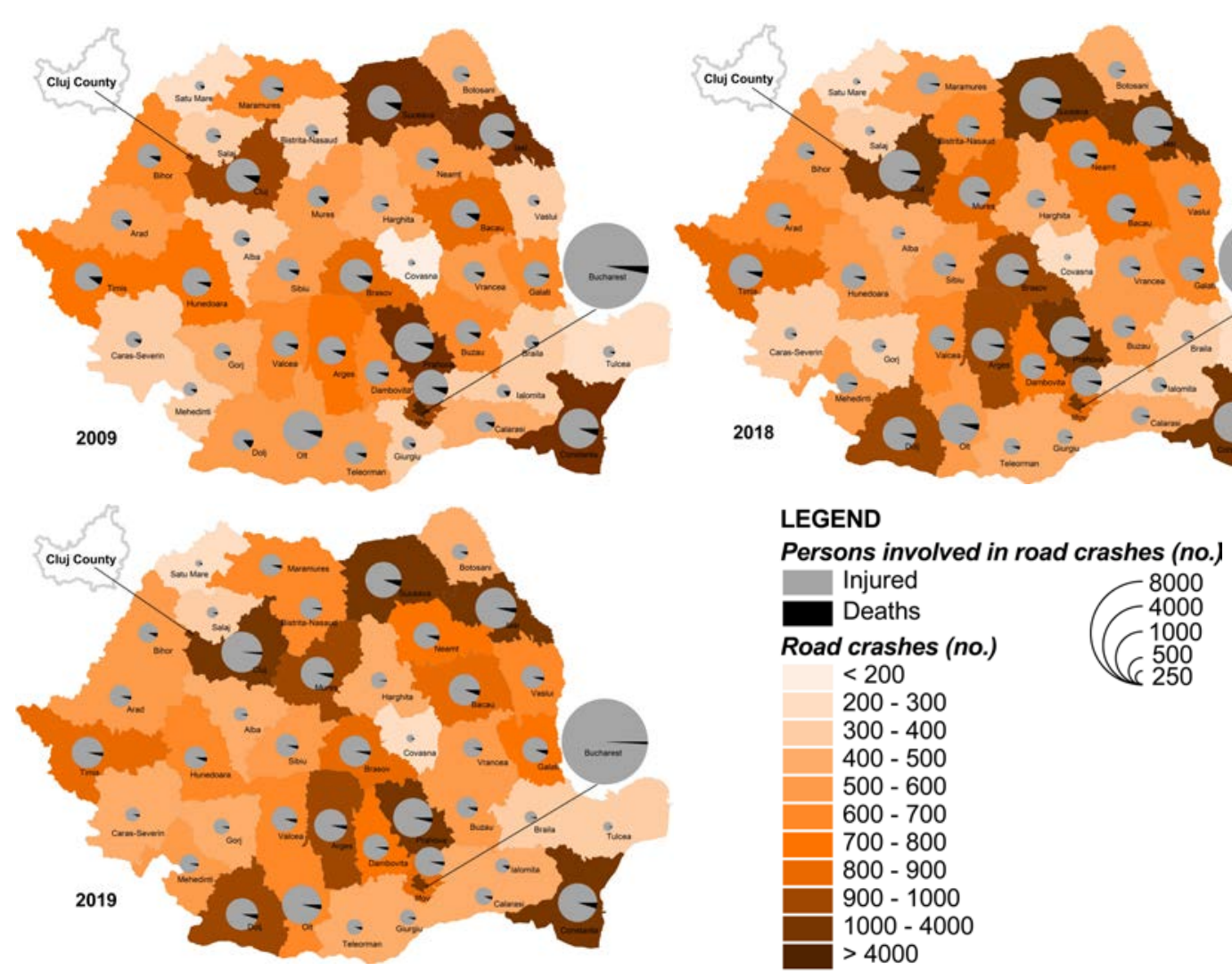

Figure 1: Territorial distribution of road crashes and the number of victims involved, in Romania, in 2009, 2018, and 2019

Source of data: National Institute of Statistics. Tempo - online database (2020)

Cluj County is a NUTS 3 region, located in north-western Romania, and it is part of the NorthWest Development Region. Within the administrative territory, we note six interconnected urban centres (Cluj-Napoca, Turda, Dej, Câmpia Turzii, Huedin and Gherla), of which the municipality of Cluj-Napoca, with its metropolitan area, is located in a central position. The road network facilitates the direct connection between the urban centres and neighbouring counties in the following directions: southeast - northwest, northwest - centre - northeast, and centre - south, and ensures accessibility to all rural areas (Figure 2). 


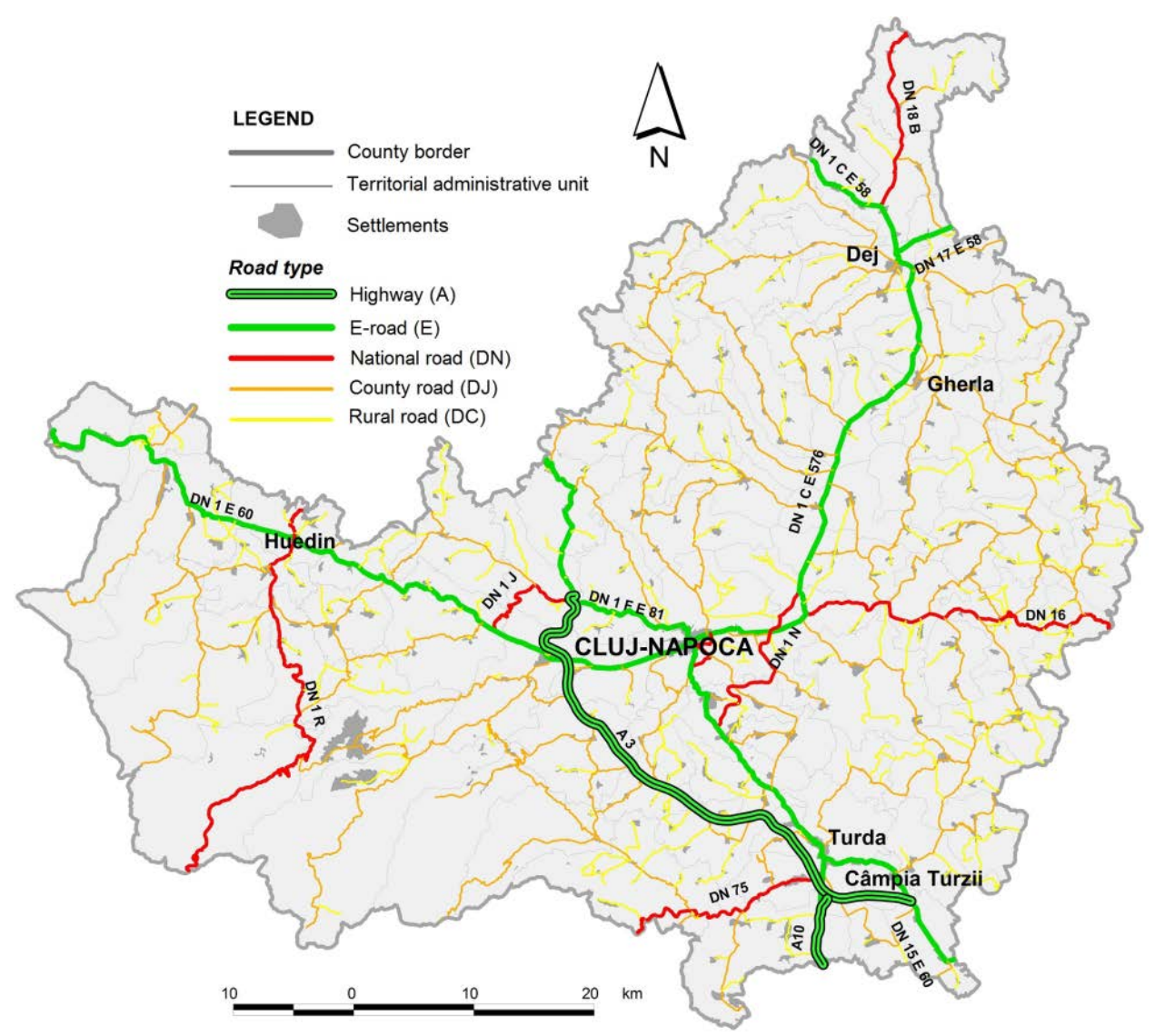

Figure 2: Cluj County road network (2019)

Source of data: The Romanian Government (2014)

Table 3: Road infrastructure in Cluj County, by type and length

\begin{tabular}{|c|c|c|}
\hline Road type & Length (km) & Share (\%) \\
\hline Highway & 68,790 & 2.48 \\
\hline E-road & 271,650 & 9.80 \\
\hline National road & 166,355 & 6.00 \\
\hline Ring road & 36,909 & 1.33 \\
\hline County road & 1336,526 & 48.21 \\
\hline Rural road & 891,953 & 32.18 \\
\hline All roads & 2772,183 & 100 \\
\hline
\end{tabular}

Source of data: Cluj County Spatial Plan (2019)

The road network is complex, consisting of all road types (highway, European, national, county and rural) together cumulating over $2,700 \mathrm{~km}$ (Table 3). However, approximately $50 \%$ of the total length is represented by county roads, which are one-lane roads with a maximum allowed speed of $50-70 \mathrm{~km} / \mathrm{h}$. The European and national roads, as the basic elements of the road network, mainly used for transit purposes with higher speeds allowed $(70-90 \mathrm{~km} / \mathrm{h}$ ), represent only $16 \%$ of the road network, and together with the highway and ring roads, hold about $20 \%$ of the total length. 


\section{Road crashes in Cluj County. Incidence and effects}

The current number of road crashes within the administrative area of Cluj County is still high, compared to the national average and especially to the European one (although, compare $d$ to 2009 , there is a general decreasing trend on all roads except for the highway, in which case cannot be the absolute and relative increase cannot be considered since in 2009 there was no highway (Table 4).

Table 4: Road crash incidence and vehicles involved in 2019 compared to 2009 and 2018

\begin{tabular}{|l|l|r|r|r|r|r|r|}
\hline \multirow{2}{*}{ Road type } & \multirow{2}{*}{ Data } & \multicolumn{4}{|c|}{ Road crashes } & \multicolumn{3}{c|}{ Vehicles involved } \\
\cline { 3 - 8 } & & $\mathbf{2 0 0 9}$ & $\mathbf{2 0 1 8}$ & $\mathbf{2 0 1 9}$ & $\mathbf{2 0 0 9}$ & $\mathbf{2 0 1 8}$ & \multicolumn{1}{c|}{$\mathbf{2 0 1 9}$} \\
\hline \multirow{2}{*}{ Highway } & no. & 0 & 7 & 5 & 0 & 12 & 10 \\
\cline { 2 - 8 } & \% & 0.00 & 0.55 & 0.73 & 0.00 & 0.57 & 0.86 \\
\hline \multirow{2}{*}{ National road } & no. & 265 & 317 & 177 & 477 & 590 & 343 \\
\cline { 2 - 8 } & \% & 29.35 & 25.10 & 25.76 & 32.99 & 28.10 & 29.42 \\
\hline \multirow{2}{*}{ County road } & no. & 67 & 110 & 54 & 97 & 163 & 76 \\
\cline { 2 - 8 } & \% & 7.42 & 8.71 & 7.86 & 6.71 & 7.76 & 6.52 \\
\hline \multirow{2}{*}{ Rural road } & no. & 14 & 30 & 12 & 15 & 39 & 15 \\
\cline { 2 - 8 } & \% & 1.55 & 2.37 & 1.75 & 1.04 & 1.86 & 1.29 \\
\hline \multirow{2}{*}{ Street } & no. & 557 & 799 & 439 & 857 & 1296 & 722 \\
\cline { 2 - 8 } & \% & 61.68 & 63.27 & 63.90 & 59.27 & 61.71 & 61.91 \\
\hline All roads & no. & $\mathbf{9 0 3}$ & $\mathbf{1 2 6 3}$ & $\mathbf{6 8 7}$ & $\mathbf{1 , 4 4 6}$ & $\mathbf{2 , 1 0 0}$ & $\mathbf{1 , 1 6 6}$ \\
\hline
\end{tabular}

Source of data: Cluj County Police Inspectorate

To observe the recent annual dynamics, and following the reporting and evaluation model at the European level, we added the data recorded in 2018 in the analysis. After a continuous increase in the number of road crashes and victims until 2018, the most significant decrease in the values of the analysed indicators is found in 2018-2019, probably due to the significant improvement of road quality of all types but also due to the implementation of proactive measures to prevent and reduce road crash occurrence, especially in the case of streets, in which case the incidence rate is the highest (Table 4).

In 2019, some 687 road crashes were registered, which proves a decrease of approximately $24 \%$ compared to the data recorded in 2009 and a decrease of approximately $45 \%$ compared to 2018 . It should be noted that, in 2018, a maximum of 1,263 road crashes was recorded (an increase of approx. $29 \%$ compared to 2009). Of these, with a view of location on road types, over $60 \%$ were concentrated on the streets of the county urban centres $(80 \%$ of them were recorded in Cluj-Napoca). Moreover, about $25 \%$ of them occurred on national and E-roads.

Regarding the vehicles involved, we note a direct correspondence with the values registered for the number of crashes on urban streets and national roads. The values of over $60 \%$ for urban streets and about $30 \%$ of vehicles involved in crashes on national roads are therefore maintained. The high values of the number of vehicles involved imply high economic costs and not only, but at the same time illustrate a pattern of road crashes (collision between vehicles). Comparatively, both the share of $60 \%$, corresponding to crashes on urban streets, and the share of $30 \%$ corresponding to crashes on national roads, are representative for the reference years, 2009 and 2018. 
Table 5: Road crash incidence and impact on persons involved in 2019 compared to 2009 and 2018

\begin{tabular}{|c|c|c|c|c|c|c|c|c|c|c|}
\hline \multirow{2}{*}{ Road type } & \multirow{2}{*}{ Data } & \multicolumn{3}{|c|}{ Persons involved } & \multicolumn{3}{|c|}{ Injured } & \multicolumn{3}{|c|}{ Fatalities } \\
\hline & & 2009 & 2018 & 2019 & 2009 & 2018 & 2019 & 2009 & 2018 & 2019 \\
\hline \multirow{2}{*}{ Highway } & no. & 0 & 16 & 11 & 0 & 15 & 11 & 0 & 1 & 0 \\
\hline & $\%$ & 0.00 & 1.00 & 1.29 & 0.00 & 0.98 & 1.32 & 0.00 & 1.49 & 0.00 \\
\hline \multirow{2}{*}{$\begin{array}{l}\text { National } \\
\text { road }\end{array}$} & no. & 477 & 496 & 276 & 416 & 465 & 268 & 61 & 31 & 8 \\
\hline & $\%$ & 35.73 & 30.90 & 32.47 & 33.79 & 30.23 & 32.17 & 58.65 & 46.27 & 47.06 \\
\hline \multirow{2}{*}{$\begin{array}{l}\text { County } \\
\text { road }\end{array}$} & no. & 117 & 156 & 72 & 110 & 147 & 70 & 7 & 9 & 2 \\
\hline & $\%$ & 8.76 & 9.72 & 8.47 & 8.94 & 9.56 & 8.40 & 6.73 & 13.43 & 11.76 \\
\hline \multirow{2}{*}{$\begin{array}{l}\text { Rural } \\
\text { road }\end{array}$} & no. & 16 & 42 & 14 & 15 & 38 & 14 & 1 & 4 & 0 \\
\hline & $\%$ & 1.20 & 2.62 & 1.65 & 1.22 & 2.47 & 1.68 & 0.96 & 5.97 & 0.00 \\
\hline \multirow{2}{*}{ Street } & no. & 725 & 895 & 477 & 690 & 873 & 470 & 35 & 22 & 7 \\
\hline & $\%$ & 54.31 & 55.76 & 56.12 & 56.05 & 56.76 & 56.43 & 33.65 & 32.84 & 41.18 \\
\hline All roads & no. & 1,335 & 1,605 & 850 & 1,231 & 1,538 & 833 & 104 & 67 & 17 \\
\hline
\end{tabular}

Source of data: Cluj County Police Inspectorate
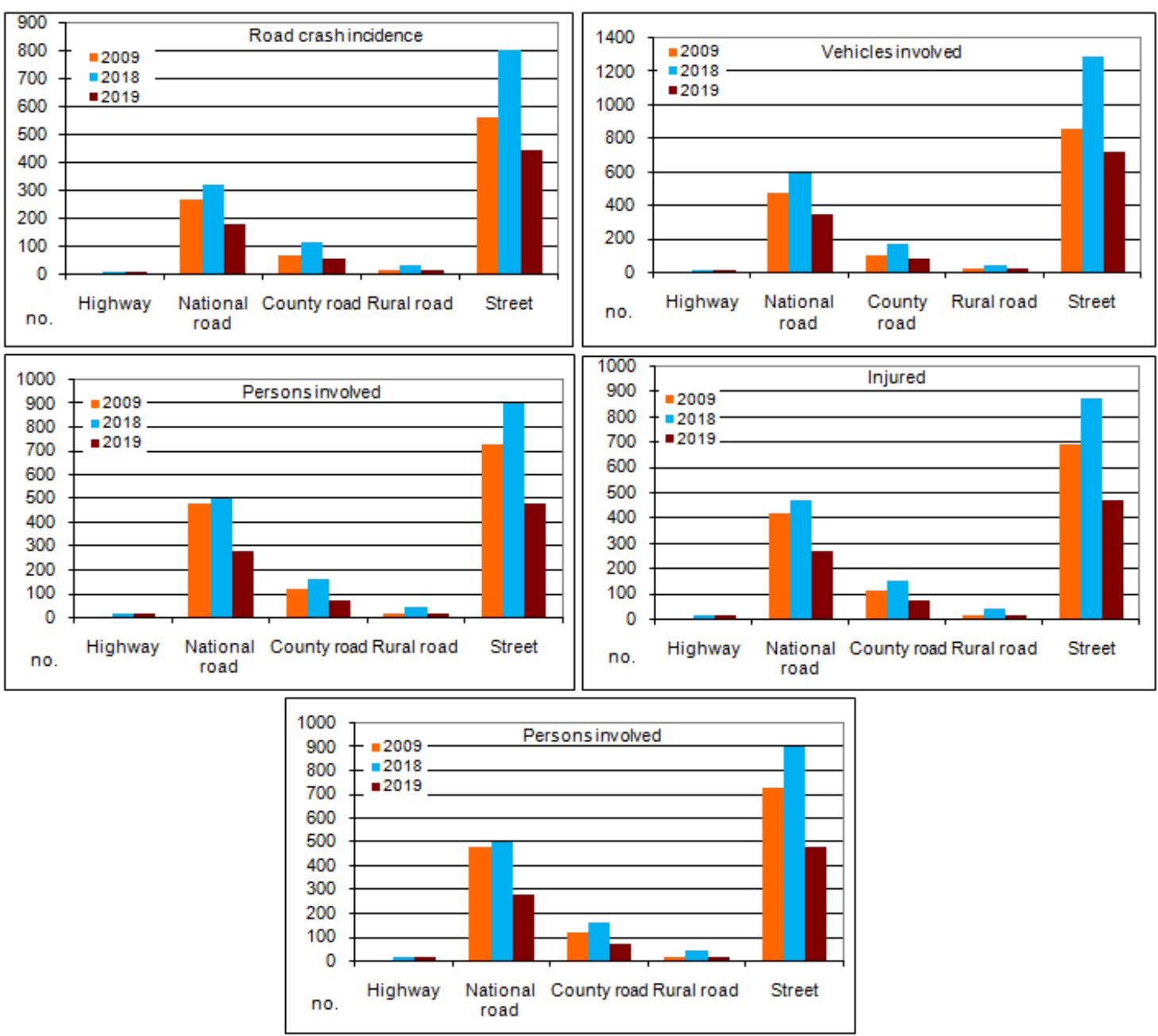

Figure 3: Road crash dynamics and their impact, by road type, recorded in the reference years 2009, 2018 and 2019 
In terms of the number of victims involved, slightly and severely injured or dead at the sce ne, we found a significant decrease, the value of 850 people involved in road crashes in Cluj County in 2019 being about 36\% lower than the value recorded in 2009 and representing about half of the value recorded in 2018 (Table 5). Of the total number of people involved, $98 \%$ are injured (minor or serious) and $2 \%$ are dead at the time of the crash. An important aspect is the decrease in the values of deaths, in 2018 their number being doubled $(4.17 \%)$, and in 2009 being almost four times higher (7.80\%) than the value registered in 2019. It should be noted the share almost equal to the number of deaths caused by crashes on national roads and those occurred on urban streets, so that, in 2019, 30\% of road crashes were accounted for $50 \%$ of deaths and about $30 \%$ of injured people (occurred on national roads), and about $60 \%$ of them (occurring on urban streets) were the cause for over $40 \%$ of road deaths.

Moreover, compared to 2009 and 2018, when crashes on urban streets were causing about $30 \%$ of deaths, in 2019 we see an increase of almost $10 \%$ of these values. On the other hand, in the case of crashes on national roads in 2009, which caused almost $60 \%$ of deaths, in 2019 we observe a decrease in these values of up to about $47 \%$, a value very close to that recorded in 2018.

Table 6: Road crash dynamics and their impact, by road type, between 2009 and 2019

\begin{tabular}{|l|c|c|c|c|c|c|c|c|c|c|}
\hline \multirow{2}{*}{$\begin{array}{l}\text { Road } \\
\text { type }\end{array}$} & \multicolumn{2}{|c|}{ Road crashes } & \multicolumn{2}{c|}{ Vehicles involved } & \multicolumn{2}{c|}{ Persons involved } & \multicolumn{2}{c|}{ Injured } & \multicolumn{2}{c|}{ Fatalities } \\
\cline { 2 - 11 } & $\begin{array}{c}\text { Abs. } \\
\text { increase } \\
\text { (no.) }\end{array}$ & $\begin{array}{c}\text { Relative } \\
\text { increase } \\
\text { (\%) }\end{array}$ & $\begin{array}{c}\text { Abs. } \\
\text { increase } \\
\text { (no.) }\end{array}$ & $\begin{array}{c}\text { Relative } \\
\text { increase } \\
\text { (\%) }\end{array}$ & $\begin{array}{c}\text { Abs. } \\
\text { increase } \\
\text { (no.) }\end{array}$ & $\begin{array}{c}\text { Relative } \\
\text { increase } \\
\text { (\%) }\end{array}$ & $\begin{array}{c}\text { Abs. } \\
\text { increase } \\
\text { (no.) }\end{array}$ & $\begin{array}{c}\text { Relative } \\
\text { increase } \\
\text { (\%) }\end{array}$ & $\begin{array}{c}\text { Abs. } \\
\text { increase } \\
\text { (no.) }\end{array}$ & $\begin{array}{c}\text { Relative } \\
\text { increase } \\
\text { (\%) }\end{array}$ \\
\hline Highway & 5 & 500.00 & 10 & 1000.00 & 11 & 1100.00 & 11 & 1100.00 & 0 & 0.00 \\
\hline $\begin{array}{l}\text { National } \\
\text { road }\end{array}$ & -88 & -33.21 & -134 & -28.09 & -201 & -42.14 & -148 & -35.58 & -53 & -86.89 \\
\hline $\begin{array}{l}\text { County } \\
\text { road }\end{array}$ & -13 & -19.40 & -21 & -21.65 & -45 & -38.46 & -40 & -36.36 & -5 & -71.43 \\
\hline $\begin{array}{l}\text { Rural } \\
\text { road }\end{array}$ & -2 & -14.29 & 0 & 0.00 & -2 & -12.50 & -1 & -6.67 & -1 & -100.00 \\
\hline Street & -118 & -21.18 & -135 & -15.75 & -248 & -34.21 & -220 & -31.88 & -28 & -80.00 \\
\hline All roads & $-\mathbf{2 1 6}$ & -23.92 & -280 & -19.36 & -485 & -36.33 & -398 & -32.33 & -87 & -83.65 \\
\hline
\end{tabular}

Source of data: Cluj County Police Inspectorate

Table 7: Road crash dynamics and their impact by road type between 2018 and 2019

\begin{tabular}{|l|c|c|c|c|c|c|c|c|c|c|}
\hline \multirow{2}{*}{$\begin{array}{l}\text { Road } \\
\text { type }\end{array}$} & \multicolumn{2}{|c|}{ Road crashes } & \multicolumn{2}{c|}{ Vehicles involved } & \multicolumn{2}{c|}{ Persons involved } & \multicolumn{2}{c|}{ Injured } & \multicolumn{2}{c|}{ Fatalities } \\
\cline { 2 - 11 } & $\begin{array}{c}\text { Abs. } \\
\text { increase } \\
\text { (no.) }\end{array}$ & $\begin{array}{c}\text { Relative } \\
\text { increase } \\
\text { (\%) }\end{array}$ & $\begin{array}{c}\text { Abs. } \\
\text { increase } \\
\text { (no.) }\end{array}$ & $\begin{array}{c}\text { Relative } \\
\text { increase } \\
\text { (\%) }\end{array}$ & $\begin{array}{c}\text { Abs. } \\
\text { increase } \\
\text { (no.) }\end{array}$ & $\begin{array}{c}\text { Relative } \\
\text { increase } \\
\text { (\%) }\end{array}$ & $\begin{array}{c}\text { Abs. } \\
\text { increase } \\
\text { (no.) }\end{array}$ & $\begin{array}{c}\text { Relative } \\
\text { increase } \\
\text { (\%) }\end{array}$ & $\begin{array}{c}\text { Abs. } \\
\text { increase } \\
\text { (no.) }\end{array}$ & $\begin{array}{l}\text { Relative } \\
\text { increase } \\
\text { (\%) }\end{array}$ \\
\hline Highway & -2 & -28.57 & -2 & -16.67 & -5 & -31.25 & -4 & -26.67 & -1 & -100.00 \\
\hline $\begin{array}{l}\text { National } \\
\text { road }\end{array}$ & -140 & -44.16 & -247 & -41.86 & -220 & -44.35 & -197 & -42.37 & -23 & -74.19 \\
\hline $\begin{array}{l}\text { County } \\
\text { road }\end{array}$ & -164 & -50.91 & -239 & -53.37 & -228 & -53.85 & -217 & -52.38 & -11 & -77.78 \\
\hline $\begin{array}{l}\text { Rural } \\
\text { road }\end{array}$ & -18 & -60.00 & -24 & -61.54 & -28 & -66.67 & -24 & -63.16 & -4 & -100.00 \\
\hline Street & -360 & -45.06 & -574 & -44.29 & -418 & -46.70 & -403 & -46.16 & -15 & -68.18 \\
\hline All roads & -576 & -45.61 & -934 & -44.48 & -755 & -47.04 & -705 & -45.84 & -50 & -74.63 \\
\hline
\end{tabular}

Source of data: Cluj County Police Inspectorate 
The values of both absolute and relative increase confirm this decreasing trend in road crash incidence, the general trend for the period 2009-2019 being confirmed by the dynamics recorded for the last one-year period (2018-2019). The most spectacular and gratifying reductions are found in the case of deaths, especially on national roads and urban streets where the incidence rate is quite high (see Tables 6 and 7).

\section{Spatial distribution of road crashes in Cluj County. Rural and urban incidence}

A detailed analysis, focusing on the exact road crash occurrence at the locality level, highlights a completely different reality from the macroterritorial perception. In this sense, we can observe a distinctive spatial concentration of road crashes, correlated with their number and causality, an approach that allows for the identification of hotspots or black spots (dangerous locations) generating crash occurrence, and which implies more in-depth analyses of this phenomenon.

Table 8: Road crash incidence and impact in rural and urban areas and the county level, in 2019, compared to 2009 and 2018

\begin{tabular}{|c|c|c|c|c|c|c|c|c|}
\hline \multirow[t]{2}{*}{ No. } & \multirow[t]{2}{*}{ Area } & \multirow[t]{2}{*}{ Year } & \multirow{2}{*}{$\begin{array}{l}\text { Total no. } \\
\text { of crashes }\end{array}$} & \multirow{2}{*}{$\begin{array}{c}\text { Total no. of } \\
\text { persons } \\
\text { involved }\end{array}$} & \multicolumn{2}{|c|}{$\begin{array}{c}\text { No. of injured } \\
\text { persons }\end{array}$} & \multicolumn{2}{|c|}{$\begin{array}{c}\text { No. of deceased } \\
\text { persons }\end{array}$} \\
\hline & & & & & no. & $\%$ & no. & $\%$ \\
\hline \multirow{3}{*}{1} & \multirow{3}{*}{$\begin{array}{l}\text { Cluj } \\
\text { County }\end{array}$} & 2009 & 903 & 1,335 & 1,231 & 92.21 & 104 & 7.79 \\
\hline & & 2018 & 1,263 & 1,605 & 1,538 & 95.82 & 67 & 4.18 \\
\hline & & 2019 & 687 & 850 & 833 & 98.00 & 17 & 2.00 \\
\hline \multirow{3}{*}{2} & \multirow{3}{*}{$\begin{array}{l}\text { Urban } \\
\text { areas }\end{array}$} & 2009 & 563 & 731 & 695 & 95.08 & 36 & 4.92 \\
\hline & & 2018 & 721 & 811 & 789 & 97.29 & 22 & 2.71 \\
\hline & & 2019 & 412 & 460 & 453 & 98.48 & 7 & 1.52 \\
\hline \multirow{3}{*}{3} & \multirow{3}{*}{$\begin{array}{l}\text { Rural } \\
\text { areas }\end{array}$} & 2009 & 340 & 604 & 536 & 88.74 & 68 & 11.26 \\
\hline & & 2018 & 542 & 794 & 749 & 94.33 & 45 & 5.67 \\
\hline & & 2019 & 275 & 390 & 380 & 97.44 & 10 & 2.56 \\
\hline
\end{tabular}

Source of data: Cluj County Police Inspectorate

Table 9: Road crash incidence by road type, in rural and urban areas and at the county level, in 2019, compared to 2009 and 2018

\begin{tabular}{|c|c|c|c|c|c|c|c|c|c|c|c|c|c|}
\hline \multirow{3}{*}{ No. } & \multirow{3}{*}{ Area } & \multirow{3}{*}{ Year } & \multirow{3}{*}{$\begin{array}{c}\text { Total } \\
\text { no. of } \\
\text { crashes }\end{array}$} & \multicolumn{10}{|c|}{ Number of crashes by road type } \\
\hline & & & & \multicolumn{2}{|c|}{ Highway } & \multicolumn{2}{|c|}{$\begin{array}{c}\text { National } \\
\text { road }\end{array}$} & \multicolumn{2}{|c|}{ County road } & \multicolumn{2}{|c|}{ Rural road } & \multicolumn{2}{|c|}{ Street } \\
\hline & & & & no. & $\%$ & no. & $\%$ & no. & $\%$ & no. & $\%$ & no. & $\%$ \\
\hline \multirow{3}{*}{1} & \multirow{3}{*}{$\begin{array}{l}\text { Cluj } \\
\text { County }\end{array}$} & 2009 & 903 & 0 & 0.00 & 265 & 29.35 & 67 & 7.42 & 14 & 1.55 & 557 & 61.68 \\
\hline & & 2018 & 1,263 & 7 & 0.55 & 317 & 25.10 & 110 & 8.71 & 30 & 2.37 & 799 & 63.27 \\
\hline & & 2019 & 687 & 5 & 0.73 & 177 & 25.76 & 54 & 7.86 & 12 & 1.75 & 439 & 63.90 \\
\hline \multirow{3}{*}{2} & \multirow{3}{*}{$\begin{array}{l}\text { Urban } \\
\text { areas }\end{array}$} & 2009 & 563 & 0 & 0.00 & 14 & 2.49 & 0 & 0.00 & 0 & 0.00 & 549 & 97.51 \\
\hline & & 2018 & 721 & 0 & 0.00 & 11 & 1.53 & 0 & 0.00 & 0 & 0.00 & 710 & 98.47 \\
\hline & & 2019 & 412 & 1 & 0.24 & 10 & 2.43 & 1 & 0.24 & 0 & 0.00 & 400 & 97.09 \\
\hline \multirow{3}{*}{3} & \multirow{3}{*}{$\begin{array}{l}\text { Rural } \\
\text { areas }\end{array}$} & 2009 & 340 & 0 & 0.00 & 253 & 74.41 & 67 & 19.71 & 12 & 3.53 & 8 & 2.35 \\
\hline & & 2018 & 542 & 7 & 1.29 & 306 & 56.35 & 110 & 20.26 & 29 & 5.34 & 90 & 16.57 \\
\hline & & 2019 & 275 & 4 & 1.45 & 162 & 58.91 & 53 & 19.27 & 12 & 4.36 & 44 & 16.00 \\
\hline
\end{tabular}




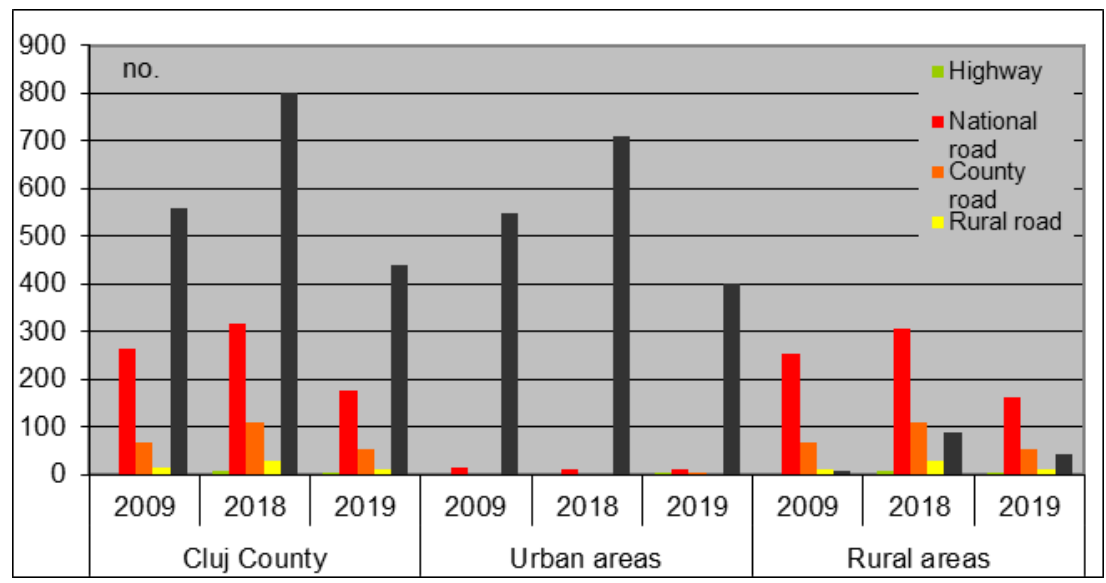

Figure 4: Road crash incidence by road type, in rural and urban areas and at the county level, in 2019 compared to 2009 and 2018

Source of data: Cluj County Police Inspectorate

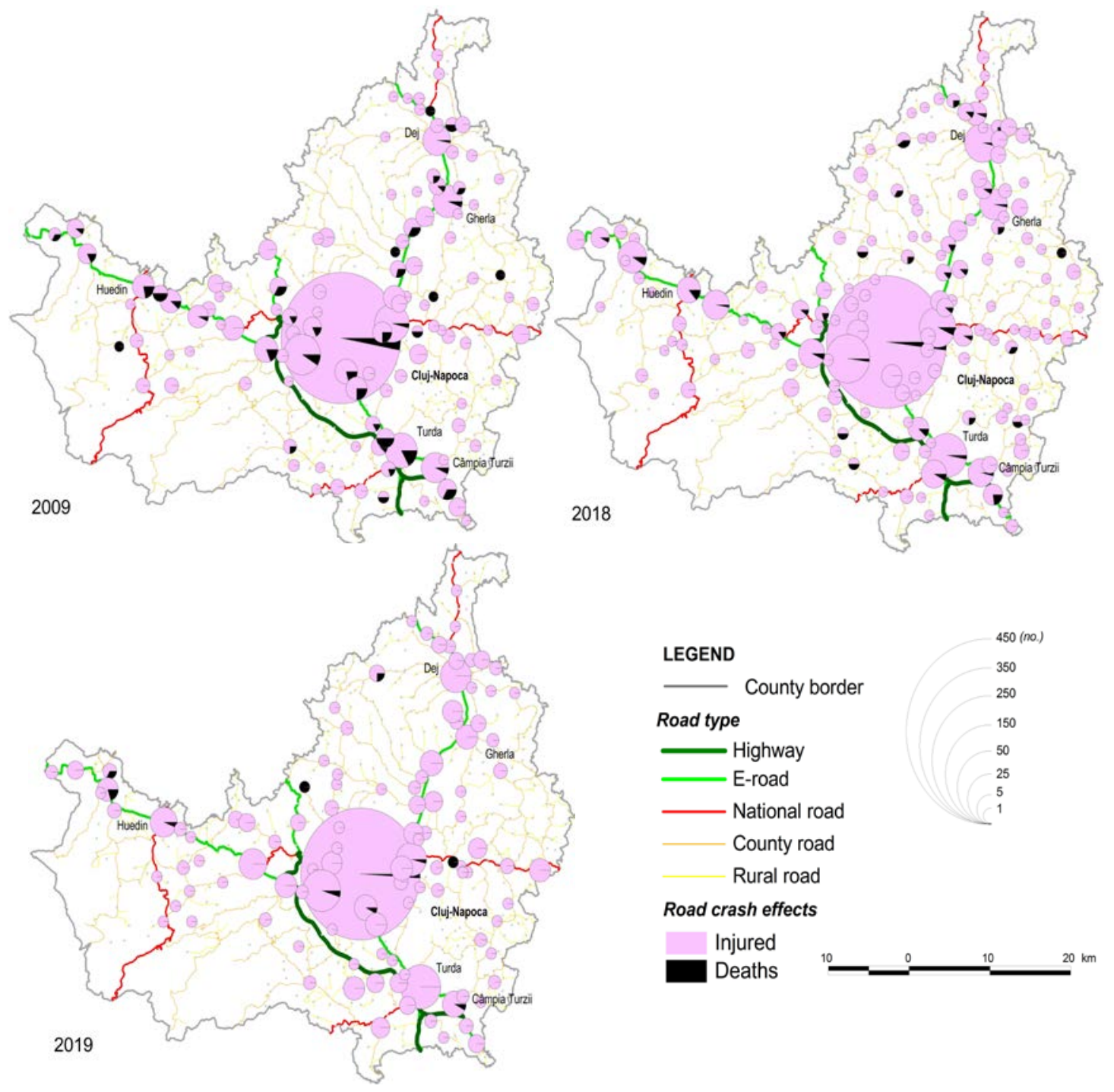

Figure 5: Spatial distribution of road crashes in Cluj County Source of data: Cluj County Police Inspectorate 
There is a great difference in both the incidence and distribution of road crashes within the administrative territory of the county. The differences in the number of road crashes record ed in urban and rural areas, with a clear dominance of those occurred in urban areas reflect particular contexts of crash occurrence (see Table 8, Table 9, Figure 4, Figure 5). The spatial differentiation is visible also for rural areas, the higher crash incidence being specific to the rural localities included in the first ring of Cluj Metropolitan Area and the rural localities crossed by national roads.

Road crash occurrence results from a complex combination of determining factors, human (related to participants in traffic - drivers and pedestrians), technical (vehicle-related) or natural and environment-related (Table 10). Driving skills and behaviour of traffic participants are, however, highly decisive in terms of road safety. From the data recorded for each road crash in Cluj County in 2019 results a wide range of determining causes that are found representative in both urban and rural areas.

\section{Table 10: Triggering factors for road crashes, as registered in 2019}

\begin{tabular}{|l|l|}
\hline $\begin{array}{l}\text { Human-related } \\
\text { factors/causes } \\
\text { Driver - related }\end{array}$ & $\begin{array}{l}\text { not maintaining safe distance between vehicles; failing to yield the } \\
\text { right of way to vehicles; failing to yield the right of way to pedestrians; } \\
\text { careless cycling; reckless driving when changing lanes; overtaking } \\
\text { while ignoring road signs; ignoring traffic lights; over speeding; wrong- } \\
\text { way driving; reckless driving in reverse; offences related to animal- } \\
\text { drawn vehicles; reckless driving when changing direction; ignoring } \\
\text { signs when crossing the railway; making illegal U-Turns for switching } \\
\text { directions of travelling; falling asleep while driving; driving without a } \\
\text { license; drink-driving; other driving offences }\end{array}$ \\
\hline $\begin{array}{l}\text { Human-related } \\
\text { factors/causes } \\
\text { Pedestrian - related }\end{array}$ & $\begin{array}{l}\text { jaywalking } \\
\text { pedestrians on the road } \\
\text { other pedestrian offences }\end{array}$ \\
\hline Technical causes & vehicle mechanical failure; overloaded vehicles \\
\hline $\begin{array}{l}\text { Land and environment } \\
\text { related }\end{array}$ & over speeding (speed not adapted to road conditions) \\
\hline
\end{tabular}

Source of data: Cluj County Police Inspectorate

At the county level in 2019, the causes triggering crashes were ranked in relation to their impact (number of crashes caused) in the following order: not maintaining a safe distance between vehicles (over $15 \%$ of crashes), failing to yield the right of way to vehicles (about $13 \%)$; over speeding (speed not adapted to road conditions) - 13\%; careless cycling and jaywalking, both with shares of almost $10 \%$; failing to yield the right of way to pedestrians about $6.70 \%$ and reckless driving when changing direction - more than $5 \%$.

Looking 10 years back, we notice that the main determining causes have changed their position in the ranking (Table 11). Whilst in 2019, almost 50\% of crashes were strictly the result of driver behaviour, mostly related to tailing, over speeding and failing to yield the right of way to vehicles and the following about $20 \%$ of crashes were having the behaviour of other participants in traffic (bikers and pedestrians) as a direct cause, in 2009, the first four triggering factors are related equally to both drivers and pedestrians (over speeding, jaywalking and failing to yield the right of way to vehicles and pedestrians). 
Table 11: Ranking road crash causes at the county level. Comparative analysis between 2019 and 2009 and 2018

\begin{tabular}{|c|c|c|c|}
\hline Rank & 2019 & 2009 & 2018 \\
\hline 1 & $\begin{array}{l}\text { not maintaining a safe } \\
\text { distance between vehicles - } \\
15 \%\end{array}$ & $\begin{array}{l}\text { over speeding (speed not } \\
\text { adapted to road conditions) } \\
-22 \%\end{array}$ & $\begin{array}{l}\text { over speeding (speed not } \\
\text { adapted } \quad \text { to road } \\
\text { conditions) }-17 \%\end{array}$ \\
\hline 2 & $\begin{array}{l}\text { failing to yield the right of } \\
\text { way to vehicles }-13 \%\end{array}$ & jaywalking $-17 \%$ & $\begin{array}{l}\text { failing to yield the right of } \\
\text { way to vehicles }-13 \%\end{array}$ \\
\hline 3 & $\begin{array}{l}\text { over speeding (speed not } \\
\text { adapted to road conditions) - } \\
13 \%\end{array}$ & $\begin{array}{l}\text { failing to yield the right of } \\
\text { way to vehicles }-16 \%\end{array}$ & $\begin{array}{l}\text { not maintaining a safe } \\
\text { distance between vehicles } \\
-13 \%\end{array}$ \\
\hline 4 & jaywalking - 10\% & $\begin{array}{l}\text { failing to yield the right of } \\
\text { way to pedestrians }-15 \%\end{array}$ & jaywalking - $10 \%$ \\
\hline 5 & careless cycling - 9\% & $\begin{array}{l}\text { not maintaining a safe } \\
\text { distance between vehicles - } \\
6 \%\end{array}$ & $\begin{array}{l}\text { failing to yield the right of } \\
\text { way to pedestrians }-10 \%\end{array}$ \\
\hline 6 & $\begin{array}{l}\text { failing to yield the right of } \\
\text { way to pedestrians }-7 \%\end{array}$ & careless cycling $-5 \%$ & careless cycling - 6\% \\
\hline 7 & $\begin{array}{l}\text { reckless driving when } \\
\text { changing direction }-5 \%\end{array}$ & $\begin{array}{l}\text { reckless driving } \\
\text { changing lanes }-4 \%\end{array}$ & $\begin{array}{l}\text { overtaking while ignoring } \\
\text { road signs }-3 \%\end{array}$ \\
\hline
\end{tabular}

Source of data: Cluj County Police Inspectorate

In urban areas, the current main factors responsible for $50 \%$ of crashes are failing to yield the right of way to vehicles and not maintaining a safe distance between vehicles, jaywalking, careless cycling, and failing to yield the right of way to pedestrians. In rural areas, most of the crashes are caused by over speeding, not maintaining a safe distance between vehicles, failing to yield right of way to vehicles, overtaking while ignoring road signs, careless cycling, jaywalking, and drink-driving.

However, we must note the differences in shares regarding the number of crashes recorded in rural areas, by cause. Compared to 2009, when crashes caused by over speeding represented about $40 \%$, in 2019 they are almost halved and the same is observed for jaywalking-related crashes, whilst in the case of other factors the number of crashes almost doubled (tailing/not maintaining safe distance between vehicles, careless cycling or falling asleep when driving).

Road crashes are conditioned by traffic flows and their intensity, and, in the absence of highways, they mainly occur on national roads. The localities crossed by these roads have the highest incidence of road crashes, and the dominant cause is not only over speeding but also other causes, such as not maintaining a safe distance between vehicles and failing to yie ld the right of way to vehicles (Figures 5, 6a, 6b and 6c).

The highest incidence is recorded on DN1 / E60 (Turda - Cluj-Napoca-Oradea), in which case transit traffic overlaps commuting, and causes oversized traffic and congestion. Moreover, DN1 is the main artery that drains the external flow to the western border of Romania with Hungary. The route of DN 1 is through the built-up area of localities, affected already by local and transit traffic, including pedestrians, animal-drawn vehicles, or the current one with in the locality. On this route, there are several localities that have kept high values in the number of crashes in the last 10 years, namely Feleacu, Vâlcele, Florești, Căpuș, Păniceni, Poieni, Ciucea and Negreni. 


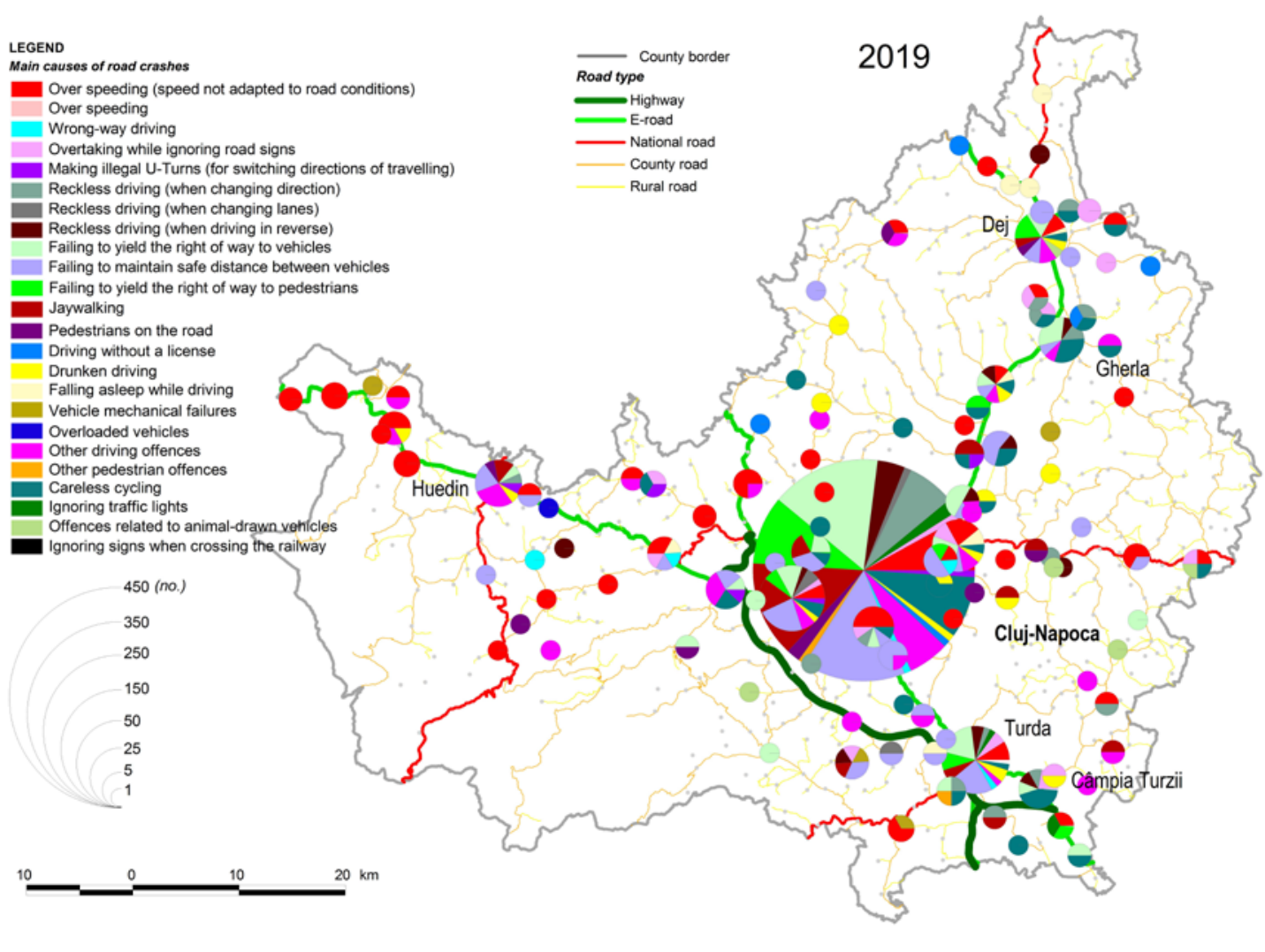

Figure 6a: Major causes of road crashes in Cluj County (2019)

Source of data: Cluj County Police Inspectorate

There are three other routes with lower but still high values of road crashes: DN 1C / E576 (Cluj-Napoca - Dej) with the following localities at high risk for crash occurrence: Dezmir, Apahida, Juc-Herghelie, Bonțida, Iclod, Livada and Bunești; DN 1F / E81 (Cluj-Napoca - Zalău) on which route the localities of Baciu, Nădășelu, Sânpaul and Topa Mică are found prone to crash occurrence; DN 16 (Cluj-Napoca - Reghin), with three sections where road crash occurrence is high, namely in the localities of Corpadea, Căianu and Mociu, here the main cause being the combination of transit traffic with the usual local traffic within the built up area of localities and the low quality of the road.

In the case of county roads, once with the beginning of modernization programme-Regional Operational Programme, in which several county road sections were included (DJ 108B DejBobâlna-Surduc, DJ 109A Cluj-Napoca-Chinteni-Panticeu, DJ 103K Căpușu Mare-Dangău-RîșcaBeliș, DJ 108C Mănăstireni-Călata-Mărgău, DJ 161D Dej-Nireș-Unguraș), there is an increase in the incidence caused by over speeding, paradoxically due to the high quality of road infrastructure. Rural roads remain the safest roads where the crash incidence rate is minimal. 


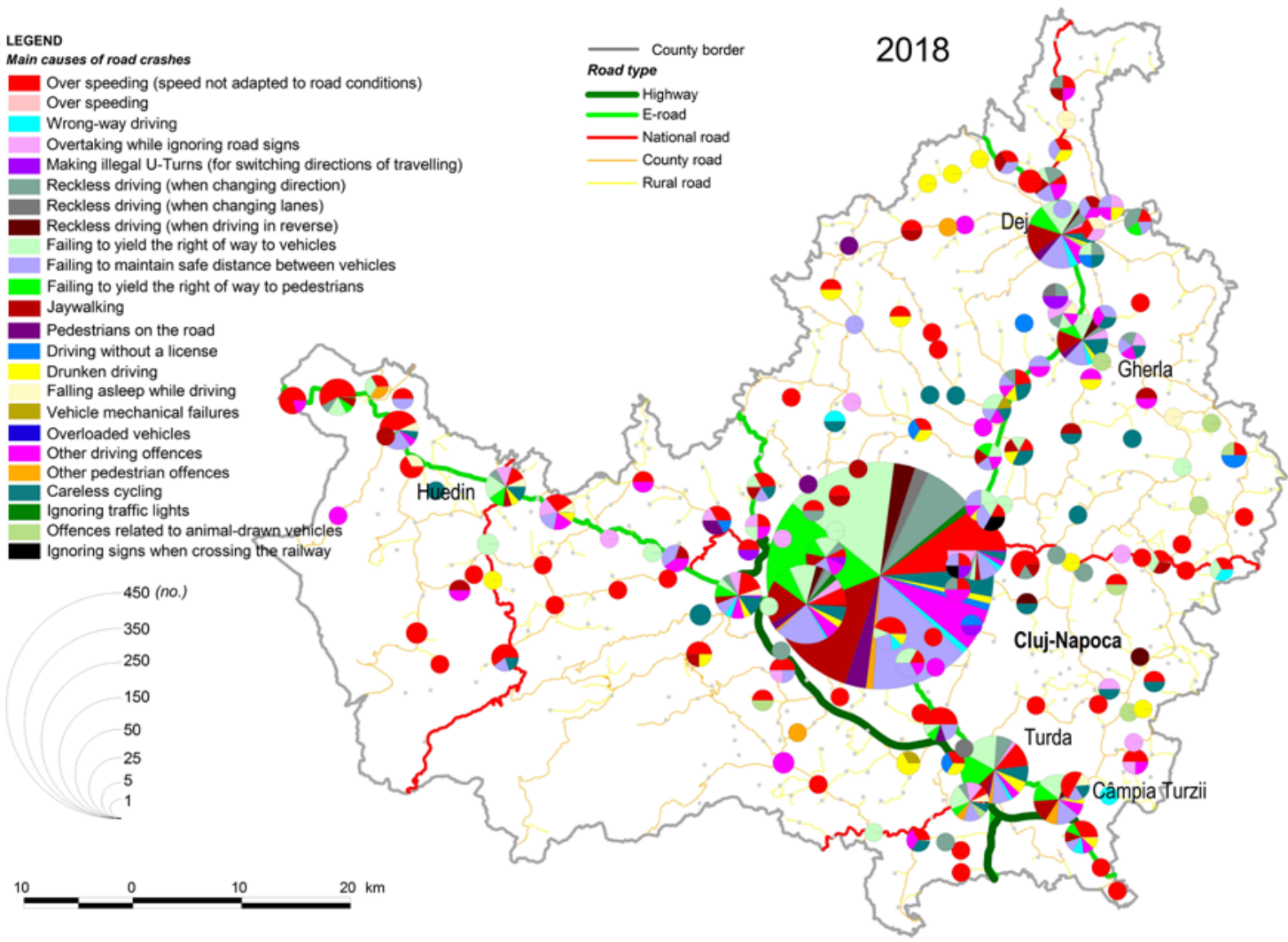

Figure 6b: Major causes of road crashes in Cluj County (2018)

Source of data: Cluj County Police Inspectorate

\section{LEGEND}

Main causes of raad crashes

Over speeding (speed not adapted to road conditions)

Over speeding

$y$ driving

Overtaking while ignoring road signs

Making illegal U-Turns (for switching directions of travelling)

Reckless driving (when changing direction)

Reckless driving (when changing lanes)

Reckless driving (when driving in reverse)

Failing to maintain sate distance between vehicles

Failing to yield the right of way to pedestrians

Jaywalking

Pedestrians on the road Driving without a license Drunken driving Falling asleep while drivin

Oenicle mechanical falures

Overloaded vehicles

Other driving offences

Careless cycling

Ignoring traffic lights
Offences related to animal-drawn venticles

Ignoring signs when crossing the railway
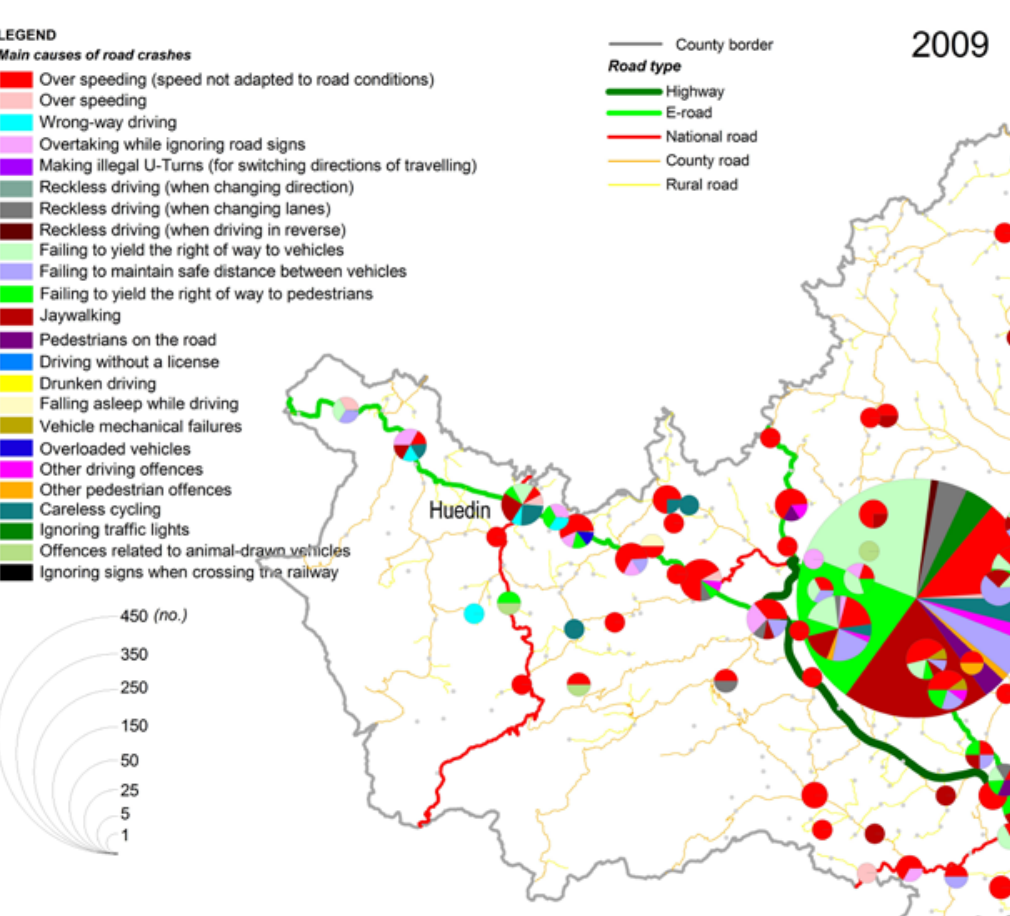
The fact that two sections of A3 highway Câmpia Turzii - Turda - Gilău - Nădășelu and A10 highway Aiud - Turda have become operative, did not lead to the expected decrease in traffic values and, implicitly, in road crash incidence. This is due primarily to a not fully integrated connectivity within the road network, which makes them ease the traffic flow only on one major direction, south, southeast - west, northwest. Another contributory factor for the observed distribution of crash incidence is the lack of ring roads in the main rural localities transited by national roads and some of the cities (Câmpia Turzii, Turda, Dej, Huedin), as well as their incomplete configuration in the case of Cluj-Napoca and Gherla.

Relative to the patterns of road crash occurrence at the national level, Cluj County falls within some of the aspects concluded in 2019 by the Romanian Police in the report on traffic and road safety on the Romanian roads. From the spatial perspective, data regarding road cras hes occurred in Cluj County in 2019 show the following distinctive features:

- crashes on the streets in urban areas have the highest share in the total number at the county level (more than 60\%), mostly distributed in the built-up area of Cluj-Napoca city (80\%). Unlike the general national pattern according to which the highest number of crashes usually occur on the streets in the built-up area of cities, yet with a lower impact on human life (the lowest death rate), in the case of Cluj County, the number of persons involved (injured or deceased) is the highest as well, meaning that the socioeconomic impact is clearly significant. Crashes on the streets of urban areas account for more than $50 \%$ of the total injured and for more than $40 \%$ of the total deaths.

- the lowest number of road crashes occurs on the highway (less than $1 \%$ of the total number at the county level), in this case crashes involving more the one vehicle and having multiple injured, yet no fatalities, against the usual devastating impact imposed by the high speed of circulation on this type of road.

- although with a speed limit of $50-70 \mathrm{~km} / \mathrm{h}$, traffic on county roads shows a rather low safety level, as well, about $7 \%$ of the crashes recorded on the county roads were accounted for $11 \%$ of deaths and some $8 \%$ injured. They occur in rural areas and urban areas.

\section{CONCLUSIONS}

Efforts have been made to create policies, measures and programmes to enhance road safety, as a top priority promoted at the global, European and national level. However, if analysed at different spatial scales, the effects of policies and the degree of achieving the road safety objectives set at international and national level may vary. This study aims to illustrate what are the main causes triggering road crashes in Cluj County at present, compared to 2009, what were the dynamics in the road crash incidence in the last ten years and how are road crashes distributed spatially in urban and rural areas and in relation with the road type.

The distinctive features of road safety in Cluj County, Romania, are directly related to the road configuration, road quality and the size of the traffic, expressed by the behaviour of drivers and pedestrians. Compared to 2009, in 2019 there is an overall decrease of about $25 \%$ in the number of road crashes at the county level, yet without visible changes in their share by road type, most of them still occurring on the streets of urban areas and on national roads. The impact illustrated by the degree of severity of injuries produced to the victims involved, including death, shows a general decline in the number of people involved, with an 
extraordinary decrease in the number of deaths caused by road crashes, values recorded in 2019 being about four times lower than those in 2009. Despite these encouraging data, we need to emphasise the increase of about $10 \%$ in the share of dead on the urban streets and national roads. Regarding the causes, we must note three main triggering factors determining about $50 \%$ of road crashes. Compared to the context in 2009 , over speeding is not the first cause anymore. The major causes in 2019 reflect a particular feature of the drivers, that of lack of patience and attention expressed by specific actions, namely not maintaining a safe distance between vehicles and failing to yield the right of way to vehicles, besides over speeding.

Finally, the results prove a certain degree of efficiency of the measures implemented at the national and local level, which further confirm the possibility of meeting the targets regarding road safety set at the international level, either fully or partially. There is more effort to be made by the local and national authorities to persistently engage in the implementation of practical measures to mitigate crash occurrence and meet the targets set by Agenda 2030 and the European Union's latest road safety policy for more safe, connected, and clean mobility.

This study is not without limitations, as the analysis was mainly focused on the presentation of the current status of road safety in Cluj County, Romania, illustrating the number of road crashes and their main triggering causes in 2019, compared to 2009 and 2018. This analysis aimed to reveal the influence and the effects of the European policies regarding road safety at a lower spatial scale, namely a NUTS 3 region in Romania. Descriptive statistics were used to portray the reality of road crashes within the road infrastructure of Cluj County, Romania. Whilst road crash occurrence is an illustrative indicator of road safety, the identification of causes - and considering them as minor or major risk factors for road crash occurrence - is one of the most important steps that should be taken in the creation of suitable measures and policies for traffic safety improvement. Future studies will focus on debating other complex aspects of road safety and critical road sections, transport infrastructure development, and the level and management of traffic safety.

\section{REFERENCES}

AUTORITATEA RUTIERĂ ROMÂNĂ [ROMANIAN ROAD AUTHORITY] (2020). Costuri medii ale accidentelor cu persoane decedate si ale accidentelor rutiere grave [Average Costs of Fatalities and Severe Road Crashes]. Retrieved 15 January 2020, from https://www.arr.ro/s-i-r_doc_512_costuri-medii-ale-accidentelor-cupersoane-decedate-si-ale-accidentelor-rutiere-grave_pg_0.htm

BENEDEK, J., CIOBANU, S.M., \& MAN, T.C. (2016). Hotspots and Social Background of Urban Traffic Crashes: A Case Study in Cluj-Napoca (Romania). Accident Analysis \& Prevention, 87, 117-126. DOI: https://doi.org/10.1016/j.aap.2015.11.026

CABRERA-ARNAU, C., PRIETO CURIEL, R., \& BISHOP, S.R. (2020) Uncovering the Behaviour of Road Accidents in Urban Areas. Royal Society Open Science, 7, 191739. DOI: http://dx.doi.org/10.1098/rsos.191739

CADAR, R.D., BOITOR, M.R., \& DUMITRESCU, M. (2017). Effects of Traffic Volumes on Accidents: The Case of Romania's National Roads. Geographia Technica, 12(2), 20-29. DOI: 10.21163/GT_2017.122.03

CĂLINOIU, G., MINCĂ, D.G., \& FURTUNESCU, F.L. (2012). Analysis of Traffic Accidents in Romania, 2009. Romanian Journal of Internal Medicine, 50(1), 93-101.

CAMDEN, M.C., SOCCOLICH, S.A., HICKMAN, J.S., \& HANOWSKI, R.J. (2019). Reducing Risky Driving: Assessing the Impacts of an Automatically-assigned, Targeted Web-based Instruction Program. Journal of Safety Research, 70, 105-115. DOI: https://doi.org/10.1016/j.jsr.2019.06.006

CARAȘCA, C., HOGEA, T., \& HĂDĂREANU, V. (2019). Fatal Road Traffic Accidents in Mureș County, Romania - A Retrospective Autopsy Based Study. Acta Marisiensis - Seria Medica, 65(4), 146-149. DOI: https://doi.org/10.2478/amma-2019-0024 
CIOBANU, S.M. \& BENEDEK, J. (2015) Spatial Characteristics and Public Health Consequences of Road Traffic Injuries in Romania. Environmental Engineering and Management Journal, 14, 2689-2702.

CLUJ COUNTY SPATIAL PLAN (2020). Substantiation Study on Transport and Communications in Cluj County. Cluj County Council and the World Bank. Retrieved 28 March 2020, from https://www.patjcluj.ro/en/the-projectresults/the-substantiation-studies/substantiation-study-on-transport-and-communications.html

COȘCIUG, A., CIOBANU, S.M., \& BENEDEK, J. (2017). The Safety of Transnational Imported Second-Hand Cars: A Case Study on Vehicle-to-Vehicle Crashes in Romania. Sustainability, 9, 2380; DOI:10.3390/su9122380

COUNCIL OF THE EUROPEAN UNION (2017). Council Conclusions on Road Safety - Endorsing the Valletta Declaration of March 2017. Brussels, 8 June 2017. Retrieved 30 January 2020, from https://data.consilium.europa.eu/doc/document/ST-9994-2017-INIT/en/pdf

DROSU, A., COFARU, C., \& POPESCU, M.V. (2020). Influence of Weather Conditions on Fatal Road Accidents on Highways and Urban and Rural Roads in Romania. International Journal of Automotive Technology, 21(2), 309-317. DOI 10.1007/s12239-020-0029-4

ECKHARDT, N. \& THOMAS, I. (2005). Spatial Nested Scales for Road Accidents in the Periphery of Brussels. IATSS Research, Transportation, 29(1), 66-78.

ERDOGAN, S. (2009) Explorative Spatial Analysis of Traffic Accident Statistics and Road Mortality among the Provinces of Turkey. Journal of Safety Research, 40, 341-351. DOI: 10.1016/j.jsr.2009.07.006

EUROPEAN COMMISSION (2010). Communication from the Commission to the European Parliament, The Council, The European Economic and Social Committee and The Committee of the Regions. Towards a European Road Safety Area: Policy Orientations on Road Safety 2011-2020. Brussels, 20.7.2010.

EUROPEAN COMMISSION (2018). Communication from the Commission to The European Parliament, The Council, The European Economic and Social Committee and The Committee of the Regions. Europe on the Move. Sustainable Mobility for Europe: Safe, Connected, and Clean. Brussels, 17.5.2018.

EUROPEAN COMMISSION (2019). Commission Staff Working Document. EU Road Safety Policy Framework 20212030 - Next Steps towards "Vision Zero". Brussels, 19.6.2019.

EUROPEAN COMMISSION (2020). Road Safety Facts \& Figures. Retrieved 03 March 2020, from https://ec.europa.eu/transport/road_safety/road-safety-facts-figures-1_en

EUROPEAN COMMISSION (n.d.) Road Safety Country Overview. Romania. European Road Safety Observatory. Retrieved 30 January 2020, from https://ec.europa.eu/transport/road_safety/sites/roadsafety/files/specialist/erso/pdf/country_overviews/d acota-country-overview-ro_en.pdf

GARCIA, C., VIALLON, V., BOUAOUN, L., \& MARTIN, J.-L. (2019). Prediction of Responsibility for Drivers and Riders Involved in Injury Road Crashes. Journal of Safety Research, 70, 159-167. DOI: https://doi.org/10.1016/j.jsr.2019.07.001

GICHAGA, F.J. (2017). The Impact of Road Improvements on Road Safety and Related Characteristics. IATSS Research, 40, 72-75. DOI: http://dx.doi.org/10.1016/j.iatssr.2016.05.002

HEYDARI, S., HICKFORD, A., MCILROY, R., TURNER, J., \& BACHANI, A.M. (2019), Road Safety in Low-Income Countries: State of Knowledge and Future Directions. Sustainability, 11, 6249; DOI:10.3390/su11226249

INSPECTORATUL GENERAL AL POLIȚIEI ROMÂNE - DIRECTIIA RUTIERĂ [THE GENERAL INSPECTORATE OF THE ROMANIAN POLICE - TRAFFIC DEPARTMENT] (2019). Buletinul siguranței rutiere. Raport anual, 2018 [Road Safety Bulletin. Annual Report, 2018]. Bucharest. Retrieved 15 January 2020, from https://www.politiaromana.ro/files/pages_files/RAPORT_2020_COMPLET_LOW.pdf

INSTITUTUL NATIONAL DE STATISTICĂ [NATIONAL INSTITUTE OF STATISTICS] (2020). Tempo-online Database. http://statistici.insse.ro:8077/tempo-online/

IVAN, K. \& HAIDU, I. (2012). The Spatio-Temporal Distribution of Road Accidents in Cluj-Napoca. Geographia Technica, 2, 32-38. Retrieved 15 January 2020, from http://technicalgeography.org/pdf/2_2012/04_kinga_ivan_ionel_haidu_the_spatio_temporal_distribution_ of_road_accidents_in_cluj_napoca.pdf

IVAN, K., BENEDEK, J., \& CIOBANU, S.M. (2019). School-Aged Pedestrian-Vehicle Crash Vulnerability. Sustainability, 11, 1214. DOI: $10.3390 /$ su11041214 
IVAN, K., HAIDU, I., BENEDEK, J., \& CIOBANU, S.M. (2015). Identification of Traffic Accident Risk-Prone Areas under Low-Light Conditions. Natural Hazards and Earth System Sciences, 15, 2059-2068. DOI: https://doi.org/10.5194/nhess-15-2059-2015

JONES, A.P., HAYNES, R., KENNEDY, V., HARVEY, I.M., JEWELL, T., \& LEA, D. (2008). Geographical Variations in Mortality and Morbidity from Road Traffic Accidents in England and Wales. Health \& Place, 14, 519-535. DOI: 10.1016/j.healthplace.2007.10.001

MAHATA, D., NARZARY, P.K., \& GOVIL, D. (2019). Spatio-temporal Analysis of Road Traffic Accidents in Indian Large Cities. Clinical Epidemiology and Global Health, 7, 586-591. DOI: https://doi.org/10.1016/j.cegh.2019.01.005

MINCĂ, D.G., FURTUNESCU, F.L., CĂLINOIU, G., DOMNARIU, C.D., \& COSTEA, R.V. (2013). Profile of Persons Involved in Traffic Accidents in Romania. Romanian Journal of Legal Medicine, 21(2) 155-160. DOI: 10.4323/rjlm.2013.155

OUNI, F. \& BELLOUMI, M. (2018). Spatio-temporal Pattern of Vulnerable Road User's Collisions Hot Spots and Related Risk Factors for Injury Severity in Tunisia. Transportation Research Part F, 56, 477-495. DOI: https://doi.org/10.1016/j.trf.2018.05.003

PANTEA, C., HORHAT, R., PUTNOKY S., SUCIU, O., SAS, I.T., BACEAN, C., BAGIU, R., MLADINESCU, C.F., \& VLAICU, B. (2018). Risk Behaviours for Traffic Accidents in 18-20 Years Young People Travelling with Drunk Driver of Timis County, Romania. Revista de Chimie, 69(3), 703-706.

PAPADIMITRIOU, E., FILTNESS, A., THEOFILATOS, A., ZIAKOPOULOS, A., QUIGLEY, C., \& YANNIS, G. (2019). Review and Ranking of Crash Risk Factors Related to the Road Infrastructure. Accident Analysis \& Prevention, 125, 85-97. DOI: https://doi.org/10.1016/j.aap.2019.01.002

SAEED, T.U., HALL, T., BAROUD, H., \& VOLOVSKI, M.J. (2019) Analyzing Road Crash Frequencies with Uncorrelated and Correlated Random-Parameters Count Models: An Empirical Assessment of Multilane Highways. Analytic Methods in Accident Research, 23, 100101. DOI: https://doi.org/10.1016/j.amar.2019.100101

SAKHAPOV, R. \& NIKOLAEVA, R. (2018). Traffic Safety System Management. Transportation Research Procedia, 36, 676-681. DOI: 10.1016/j.trpro.2018.12.126

SANDHYAVITRI, A., ZAMRI, WIYONO, S., \& SUBIANTORO (2017). Three Strategies Reducing Accident Rates at Black Spots and Black Sites Road in Riau Province, Indonesia. Transportation Research Procedia, 25, 2153-2166. DOI: 10.1016/j.trpro.2017.05.415

SUNDFØR, H.B., SAGBERG, F., \& HØYE, A. (2019). Inattention and Distraction in Fatal Road Crashes - Results from In-Depth Crash Investigations in Norway. Accident Analysis \& Prevention, 125, 152-157. DOI: https://doi.org/10.1016/j.aap.2019.02.004

TÂRNU, L. \& DEAC, C. (2018a). Considerations on the Right of Way as Cause of Road Accidents in Romania. MATEC Web of Conferences 184, Annual Session of Scientific Papers IMT ORADEA. DOI: https://doi.org/10.1051/matecconf/201818401012

TÂRNU, L. \& DEAC, C. (2018b). Analysis of the Evolution of the Number of Fatal Road Accidents in Romania. MATEC Web of Conferences 184, Annual Session of Scientific Papers IMT ORADEA. DOI: https://doi.org/10.1051/matecconf/201818401011

TÂRNU, L. \& DEAC, C. (2019). Analysis of the Dynamics of Road Accidents in Sibiu County, Romania, in the Period 2010-2018. IOP Conference Series: Materials Science and Engineering, 568, 012040. DOI:10.1088/1757$899 \times / 568 / 1 / 012040$

THE ROMANIAN GOVERNMENT (2014). Hotărârea Guvernului nr. 782/2014 pentru modificarea anexelor la Hotărârea Guvernului nr. 540/2000 privind aprobarea încadrării în categorii funcționale a drumurilor publice și a drumurilor de utilitate privată deschise circulației publice din 10.09.2014. [Governmental Decision no. $782 / 2014$ on the modification of appendices to the Government Decision no. 540/2000 on the approval of the classification of public roads and private utility roads open to public traffic into functional categories, dated 10.09.2014] Appendices 1-4. Published in Official Journal no. 707/29.09.2014. Retrieved 15 January 2020, from http://www.cdep.ro/pls/legis/legis_pck.htp_act?ida=126052

THE ROMANIAN PARLIAMENT (2008). Legea 265/2008 privind gestionarea siguranței circulației pe infrastructura rutieră, republicată, cu modificările și completările ulterioare [Law 265/2008 on Traffic Safety Mana g em ent on Road Infrastructure, Republished, with Subsequent Amendments and Completions]. Published in Official Journal no. 608 of 23 August 2012. Retrieved 15 January 2020, from https://www.arr.ro/Files/uploads/130Legea\%20265-2008\%20actualizata.pdf 
UNITED NATIONS (2015). Transforming Our World: The 2030 Agenda for Sustainable Development. A/RES/70/1. Retrieved 30 January 2020, from

https://sustainabledevelopment.un.org/content/documents/21252030\%20Agenda\%20for\%20Sustainable\% 20Development\%20web.pdf

WHO (2004). World Report on Road Traffic Injury Prevention. Geneva: World Health Organization.

WHO (2009). Global Status Report on Road Safety: Time for Action. Geneva. Retrieved 30 January 2020, from www.who.int/violence_injury_prevention/road_safety_status/2009.

WHO (2018). Global Status Report on Road Safety 2018. Geneva. Retrieved 30 January 2020, from https://www.who.int/publications/i/item/9789241565684\#: :text=The\%20Global\%20status\%20report\%20o n,people\%20aged\%205\%2D29\%20years.

WIJNEN, W., WEIJERMARS, W., SCHOETERS, A., van den BERGHE, W., BAUER, R., CARNIS, L., ELVIK, R., \& MARTENSEN, H. (2019). An Analysis of Official Road Crash Cost Estimates in European Countries. Safety Science, 113, 318-327. DOI: https://doi.org/10.1016/j.ssci.2018.12.004 